\title{
オンライン粒子測定装置を用いた流動層造粒機構の検討
}

\author{
林 健太朗 $12^{*}$, 綿野 哲 2

\section{Investigation of Fluidized Bed Granulation Mechanism by Using an Online Particle Size Monitoring Device}

\author{
Kentaro Hayashi ${ }^{12^{*}}$ and Satoru Watano ${ }^{2}$
}

Received 30 October 2017; Accepted 16 January 2018

\begin{abstract}
Fluidized bed granulation by spraying purified water as a binder liquid was carried out to prepare granule consisting mainly of insoluble inorganic compounds. The effect of changes in moisture content on granule growth was investigated experimentally by using an online particle imaging processor. It was found that granule growth mechanism in fluidized bed granulation can be explained by relationship between moisture content and plastic limit of the powder. Increase of mass median diameter after forming nuclear particle was observed when the moisture content exceeded the threshold of moisture content and its value was almost the same as the plastic limit. It was also indicated that the free water on the particle surface caused secondary granulation and pores in the particle caused breakage of the secondary granule in drying stage. The mass median diameter could be controlled by determining the water spraying endpoint.
\end{abstract}

Keywords: Process analytical technology, Quality by design, Process control, Fluidized bed granulation, Moisture content.

\section{1. 緒 言}

近年の医薬品製剤開発において，「品質は製品になって から検証するものではなく，設計によって製品に組み込 まれるべきもの」という Quality by Design（QbD）の概 念が浸透してきている[1]。規制当局は製薬会社に対し, QbD 実現のために，これまでの経験に基づく運用だけで なく，プロセス解析工学（PAT）を活用した製郕工程の 科学的な理解推進を期待している。アメリカ食品医薬品 局（Food and Drug Administration, FDA）からも PAT に関 するガイダンスが出ている[2]。医薬品製造におけるリス ク軽減を PAT 推進の動機としているようにも受け取るこ とができるが，その背景には，低い工程能力，それに由 来する低生産性, 供給不安, 過大なマンパワーなど, 陳 腐化した製造技術と経験に頼り科学的でない GMP が根 底にあると認識されているようである[3]。製薬会社とし ても, 製剂工程の科学的理解を深めて, プロセス最適化,

\footnotetext{
1 塩野義製薬株式会社 生産本部生産技術部 製剂部門

( ₹ 660-0813 兵庫県尼崎市杭瀬寺島 2-1-3)

Formulation Development, Production Technology Department, Manufacturing Division, SHIONOGI \& CO., LTD.

(1-3 Kuise Terajima 2-chome, Amagasaki, Hyogo 660-0813, Japan)

2 大阪府立大学大学院工学研究科

( ₹ 599-8531 大阪府堺市中区学園町 1-1)

Graduate School of Engineering, Osaka Prefecture University

(1-1 Gakuen-cho, Naka-ku, Sakai, Osaka 599-8531, Japan)

* Corresponding Author kentarou.hayashi@shionogi.co.jp
}

ならびに, プロセスの変動状況を即座に把握して品質リ スクを軽減することにより, 安定生産・生産性向上につ なげたいと考えている。最近は, PAT ッールの普及によ り, 従来のオフライン分析だけでなく, オンラインモニ タリング装置を活用した制御機構も充実してきた[4-5]。 しかし, 単に高精度の測定機器を用いて工程をモニタリ ングするだけでは, 製剤工程の科学的な理解を深めるこ とは不十分であり, PAT ツールを活用する手法の開発が 求められている。

医薬品製剤の製造における造粒の目的は，顆粒剤と錠 剂では異なり, 前者が付着性, 飛散性の防止, 含量均一 性の向上, 服用性のしやすさなどを主な目的とするのに 対し, 後者は流動性の向上, 圧縮性の向上を主な目的と している[6]。特に顆粒剤の場合, 造粒物の粒子径は, 直 接, 大きさや形状などの外観を決定するだけでなく, そ の後工程の充填・包装工程での製造性や服用性にも大き な影響を与えるため, その粒子径推移を理解し制御する ことはきわめて重要である。

流動層造粒法は, 原料の混合, 造粒, 乾燥などの工程 を同一の密閉容器内で行えるため, ほかの造粒法と比較 して, 工程数削減と交叉污染防止の観点から優れている。 流動層造粒では, 結合剂を水に溶解した水溶液を結合液 として用いることが一般的であるが, この場合, 造粒物 の組成を変えずに, 加液量を任意に変更するとことはで きない。一方, 結合剤などほかの添加剤を含まない精製 水を結合液として用いた場合, 最終製品の組成を変える 
ことなく，造粒の進行状況に合わせて加水量を任意に調 整できるため, 医薬品製造のレギュレーションの観点か ら好都合であるだけでなく，原料特性やプロセスの変動 に対応できる柔軟なプロセスとなり得る。そのため，水 を結合液として用いる系は，オンラインモニタリングに よるプロセス制御との相性もよいといえる。つまり，流 動層造粒工程における PAT を活用したリスク軽隇の戦略 として, 粒子径推移に影響を与える要因を理解すること が出発点となり，オンラインモニタリングは非常に有用 である。

これまでにも攪找造粒におけるトルクや消費電力のモ ニタリング[7-10], 赤外分光分析装置を用いた流動層造 粒に打ける含水率モニタリングおよび制御[11], 画像解 析装置やレーザー分光装置を用いた粒子径モニタリング [12-13]など，湿式造粒におけるモニタリングおよびその 終点管理に関する研究は多数報告されている。しかしな がら, 湿式造粒においては, 乾燥が必須であるため, 造 粒だけでなく乾燥までを一連の工程として粒子径推移を 理解すべきであるが，乾燥工程における粒子径変化を無 視していることがほとんどであり，流動層溶融造粒など の報告が数例あるだけで[13-15], 造粒から乾燥終点まで を対象とした粒子径推移は十分に解明されているとはい えない。

そこで本研究では, 水を結合液として用いる流動層造 粒工程において, 粒子径をオンラインモニタリングして 加水終点を制御するとともに，造粒から乾燥までの含水 率の時間変化が粒子径に与える影響を明らかにし，工程 理解を推進することを目指して, 生産スケールでの検討 を実施した。

\section{2. 実験方法}

\section{1 試料}

本実験に用いた試料は，胃潰瘍などに処方される無機 化合物を主成分とする制酸剤[16]を模して調合した。そ の組成を Table 1 に示す。工程を理解しやすい系として, 水にほとんど溶けない無機化合物を主成分とし，かつ, 片形が顆粒剤である制酸剤をモデル製剤に選択した。こ の制酸剂に含まれる乾燥水酸化アルミニウムゲルと酸化 マグネシウムに加えて, 医薬品製剂において汎用される ヒドロキシプロピルセルロースを結合剤として粉末添加 し，その他を賦形剤として試料を調製した。物理混合物 としての試料の物性を Table 2 に示す。レーザー回析式 乾式粒度分布測定装置 (HELOS \& RODOS, Sympatec $\mathrm{GmbH}$ )を用いて測定レンジ R4 で粒度分布を測定し, 質 量中位径挹よびザウター平均粒子径を求めた。粒子密度 は乾式自動密度計（AccuPyc II 1340, Shimadzu Corp.）を 用いて測定した。かさ密度は, 試料を JIS 標準篩 10 号を 通して $100 \mathrm{~mL}$ の円筒型容器内に溢れるまで流下させた 後, 注意深くすり落として測定した試料質量から求めた。 なお，試料は Geldart の分類[17]によると Group C に該当 した。

固・液・気の充填状態をトルクの推移として測定でき
Table 1 Formulation of powder samples

\begin{tabular}{lcc}
\hline & Content $[\mathrm{mass} \%]$ & Function \\
\hline Dried Aluminum hydroxide gel & 41 & Active ingredient \\
Magnesium oxide & 21 & Active ingredient \\
Hydroxypropylcellulose & 10 & Binder \\
Others & 28 & Filler \\
\hline
\end{tabular}

Table 2 Properties of powder samples as physical mixture

\begin{tabular}{lc}
\hline Mass median diameter $[\mu \mathrm{m}]$ & 11 \\
Sauter mean diameter $[\mu \mathrm{m}]$ & 3.5 \\
Particle density $\left[\mathrm{g} / \mathrm{cm}^{3}\right]$ & 2.3 \\
Bulk density $\left[\mathrm{g} / \mathrm{cm}^{3}\right]$ & 0.50 \\
\hline
\end{tabular}

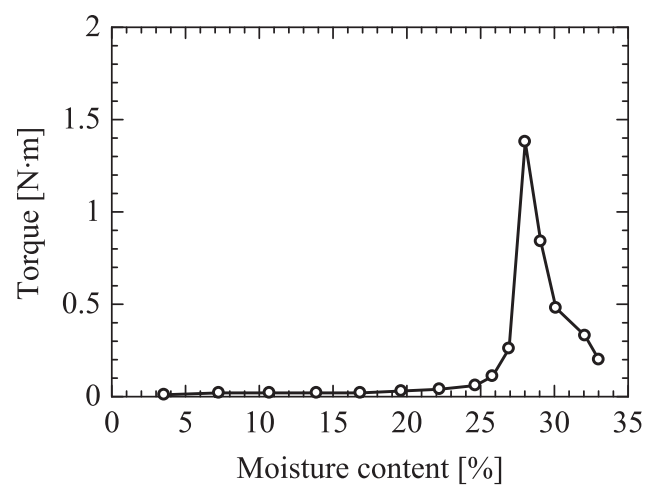

Fig. 1 Granulation torque of powder samples

るミキサートルクレオメータ (MTR-2, Caleva Process Solutions Ltd.）を用いて, 最大のトルク值を示すときの 湿量基準の含水率を可塑限界值として求めた[18-19]。試 料 $40 \mathrm{~g}$ に対し, $0.8 \mathrm{~g}$ または $1.6 \mathrm{~g}$ の精製水を順次添加し, multiple addition mode で各時点におけるトルクを測定し た。その結果を Fig. 1 に示す。本実験に用いた試料は, 含水率 $28 \%$ の時点でトルクは最大值を示した。すなわ ち, 含水率 $28 \%$ に扔いて, 粒子群内の空間に占める液体 の体積比で定義される飽和度が 1 となり, これ以上の含 水率では，一般に固体粒が液体中に懸濁するか，または その充填物から湧出する[20]。

\section{2 小スケールでの実験方法}

生産スケールでの実験に先立ち, 流動層造粒機 (FS-230, Dalton Corp.) による小スケールでの予備検討を実施し た。この流動層造粒機の缶体下部空気分散板部の内径は $0.23 \mathrm{~m}$ である。この流動層造粒機に試料 $4 \mathrm{~kg}$ を入れ, 精 製水を粉体層の上方より噴霧した。その造粒条件を Table 3 に示す。使用した粉体は粒子径が細かいためバグフィ ル夕に付着しやすいので, 造粒初期にすみやかに含水率 を増大させることにより，付着抑制を図った。さらに， 含水率の増大に伴って吸気風速を徐々に増大させ（初期 風速 $0.4 \mathrm{~m} / \mathrm{sec}$, 最大風速 $1.8 \mathrm{~m} / \mathrm{sec}$ ), 流動層高が低下し ないよう適宜調整した。造粒工程中の顆粒の含水率は適 時, 赤外線水分計 $\left(\mathrm{FD}-720\right.$, Kett Electric Laboratory, $\left.80^{\circ} \mathrm{C}\right)$ で測定した。画像解析装置（Image Eye, Dalton Corp.) を 用いて, 流動層造粒工程中の粒子径をオンライン測定し, 各時点における質量中位径を算出した[21]。 
Table 3 Operating conditions at lab-scale

\begin{tabular}{|c|c|c|c|c|}
\hline Step & Inlet air temperature $[\mathrm{K}]$ & Inlet air velocity $[\mathrm{m} / \mathrm{sec}]$ & Water feed rate per powder mass $[(\mathrm{kg} / \mathrm{min}) / \mathrm{kg}]$ & Step transfer condition \\
\hline Blend & 298 & 0.4 & NA & For $1 \mathrm{~min}$ \\
\hline Spray-1 & 298 & 0.4 to 1.2 & 0.02 & For $18 \mathrm{~min}$ \\
\hline Spray-2 & 298 & 1.2 to 1.8 & 0.01 & For $21 \mathrm{~min}$ \\
\hline Drying & 298 to 353 & 1.8 to 1.4 & $\mathrm{NA}$ & For $30 \mathrm{~min}$ \\
\hline \multicolumn{5}{|c|}{ Spraying condition } \\
\hline \multicolumn{4}{|c|}{ The number of spray nozzles [-] } & 1 \\
\hline \multicolumn{4}{|c|}{ Nozzle insert (i.d.) [mm] } & 1.0 \\
\hline \multicolumn{4}{|c|}{ Spray air pressure $[\mathrm{Pa}]$} & $4 \times 10^{5}$ \\
\hline \multicolumn{4}{|c|}{ Water feed rate per nozzle $[\mathrm{kg} / \mathrm{min}]$} & $0.02-0.08$ \\
\hline
\end{tabular}

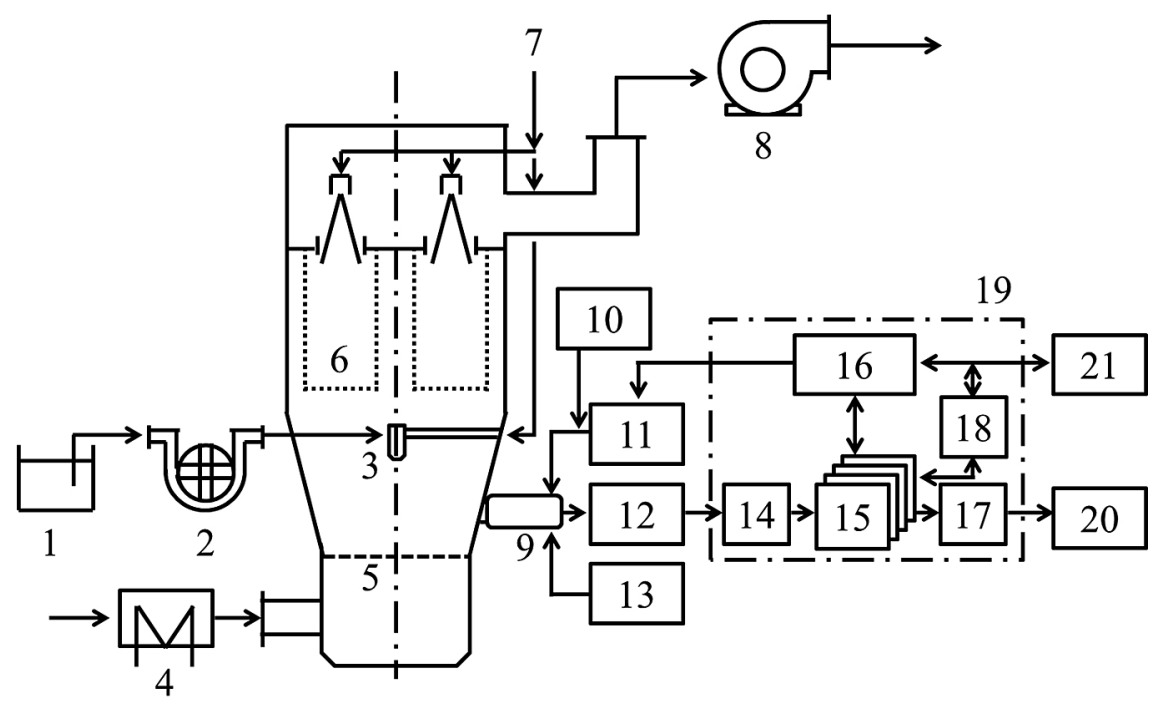

Fig. 2 Schematic diagram of the experimental apparatus employed

1, water; 2, pump; 3, spray gun; 4, heater; 5, distributer plate; 6, bag filter; 7, compressed air; 8, blower; 9, particle image probe; 10, stroboscope; 11, light source; 12, CCD camera; 13, purge air unit; 14, A/D converter; 15, frame memory; 16, image processor; 17, D/A converter; 18, microprocessor; 19, image processing unit; 20, CRT; 21 , host computer

\section{3 生産スケールでの実験装置および実験方法}

生産スケールの実験として, 本研究で用いた流動層造 粒機（NFLO-300, Freund Corp.）の概略図を Fig. 2 に示 す。この流動層造粒機の午体下部空気分散板部の内径は $1.15 \mathrm{~m}$ である。この流動層造粒機に試料 $195 \mathrm{~kg}$ を入れ, 精製水を粉体層の上方より噴霧した。小スケールでの予 備検討を参考に決めた生産スケールでの造粒条件を Table 4 に示す。小スケールから生産スケールへのスケー ルアップにあたり, 吸気風速（初期風速 $0.6 \mathrm{~m} / \mathrm{sec}$, 最大 風速 $1.8 \mathrm{~m} / \mathrm{sec}$ ）および粉体質量に対する加水速度がほほ 一定となるように条件を設定した。含水率の時間変化が 粒子径に与える影響を調べるために, 流動層造粒機の缶 体温度などを変えることにより，Fig. 3 に示す加水速度 条件（i; 標準条件, ii; 緩徐条件, iii; 急速条件) にて造粒 を実施した。小スケール実験同様, 造粒工程中の顆粒の 含水率は適時, 赤外線水分計 (FD-720, Kett Electric Laboratory, $80^{\circ} \mathrm{C}$ ) で測定し, 流動層造粒工程中の粒子径 は画像解析装置（Image Eye, Dalton Corp.) を用いてオン ライン測定した。CCD カメラへの粉付着による測定精度
低下を避けるために, 造粒開始約 25 分後から, 流動層造 粒機に画像解析装置のプローブを取り付け, 粒子径を測 定し，各時点における質量中位径を算出した。また，指 数移動平均で平滑化した質量中位径 MMDSにより, 加 水終点の制御を行った。時点 $t$ における $\mathrm{MMDS}_{t}$ を Eq. (1) に示す。

$$
\mathrm{MMDS}_{t}=\alpha \times \mathrm{MMD}_{t}+(1-\alpha) \times \mathrm{MMDS}_{t-1}
$$

なお本実験においては, 指数移動平均の重みの半減期 が約 1 分となるよう, 測定時間間隔を 10 秒, 平滑化係数 $\alpha=0.1$ として MMDS を算出した。

\section{4 造粒物の物性評価方法}

得られた造粒物の物性として, かさ密度および粒度分 布を評価した。かさ密度は, 試料を JIS 標準篩 10 号を通 して $100 \mathrm{~mL}$ の円筒型容器内に溢れるまで流下させた後, 注意深くすり落として測定した試料質量から求めた。粒 度分布は, ロータップ型節振盪機（RS-2, TANAKA TEC Corp.）を用いた篩分け法により, 各穊を通過した試料質 量を測定して求めた。 
Table 4 Operating conditions at commercial scale

\begin{tabular}{|c|c|c|c|c|}
\hline Step & $\begin{array}{l}\text { Inlet air temperature } \\
\qquad[\mathrm{K}]\end{array}$ & $\begin{array}{c}\text { Inlet air velocity } \\
{[\mathrm{m} / \mathrm{sec}]}\end{array}$ & $\begin{array}{l}\text { Water feed rate per powder mass } \\
\qquad[(\mathrm{kg} / \mathrm{min}) / \mathrm{kg}]\end{array}$ & Step transfer condition \\
\hline Blend & 298 & 0.6 & NA & For $1 \mathrm{~min}$ \\
\hline Spray-1 & 298 & 0.6 to 0.9 & 0.02 & For $25 \mathrm{~min}$ \\
\hline Spray-2 & 298 & 0.9 to 1.6 & 0.01 & When MMDS reached at $610 \mu \mathrm{m}$ or more \\
\hline Drying & 298 to 368 & 1.8 to 1.3 & NA & When outlet air temperature reached at or below $321 \mathrm{~K}$ \\
\hline \multicolumn{5}{|c|}{ Note: Fluidized bed granulator was used after warmed to i) $319 \mathrm{~K}$, ii) $337 \mathrm{~K}$, iii) $314 \mathrm{~K}$} \\
\hline \multicolumn{5}{|c|}{ Spraying condition } \\
\hline \multicolumn{4}{|c|}{ The number of spray nozzles [-] } & 9 \\
\hline \multicolumn{4}{|c|}{ Nozzle insert (i.d.) $[\mathrm{mm}]$} & 2.2 \\
\hline \multicolumn{4}{|c|}{ Spray air pressure $[\mathrm{Pa}]$} & $5 \times 10^{5}$ \\
\hline \multicolumn{4}{|c|}{ Water feed rate per nozzle $[\mathrm{kg} / \mathrm{min}]$} & $0.1-0.4$ \\
\hline
\end{tabular}

\section{3. 実験結果および考察}

\section{1 小スケールでの予備検討結果}

小スケールでの予備検討における粒子径と含水率の時 間変化を Fig. 4 に示す。本実験に用いた試料の物理混合 物は, 質量中位径が $11 \mu \mathrm{m}$ であり（Table 2), 造粒開始初 期において粒子径画像装置による測定值との間に大きな 差がみられた。さらに，加水を継続することで，粒子径 画像装置による粒子径は減少するという結果が得られた。 これは，本実験に用いた粒子径画像装置では特に $50 \mu \mathrm{m}$ 以下の粒子を測定範囲として設定しているため，微粉が 多数存在する造粒初期では, 微粉の集合体を大きな粒と 認識したことに起因すると考えられる。加水を継続して, ある程度造粒が進行し粒が形成された後は，画像解析装 置および篩分け法により造粒進行とともに増大する粒子 径を確認することができた。

\section{2 含水率の時間変化が粒子径に与える影響}

生産スケールにて異なる加水速度で造粒操作を行った 際の総加水量を Table 5 に示す。加水速度が急速なほど, 総加水量, すなわち, 所定の質量中位径に到達するため に要する加水量は少なかった。Fig. 5～Fig. 7 に各造粒条 件における質量中位径と含水率の時間変化をそれぞれ示 す。加水停止時点を図中に矢印で示した。造粒工程中の 含水率を変化させた各条件において，質量中位径の変化 と造粒工程中の含水率との間に以下の特徵的な共通点が 認められた。まず，粒子径測定を開始して以降，試料の 可塑限界值相当の含水率約 $28 \%$ 閾值として，これを超 えるまで質量中位径の変化がほとんどない，または緩や かであった（段階 I）。そして，含水率が闇值を上回った 時点で質量中位径は顕著に増大した（段階 II）。この質量 中位径の増加は加水を停止しても継続した。さらに, 乾 燥が進行し，含水率が闇值を下回ったとき，質量中位径 が最大值に達した。その後，質量中位径の減少が進んだ (段階 III)。このように，可塑限界值相当の閾值と加水速 度に基づき，造粒工程を（I）〜（III）の三段階に分類す ることができた。

\section{3 顆粒物性評価}

各造粒条件で得られた造粒物の粒度分布およびかさ密

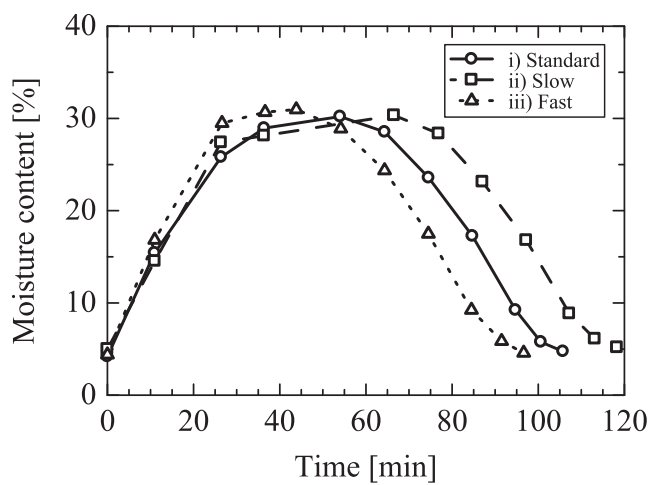

Fig. 3 Changes in moisture content in granulation process
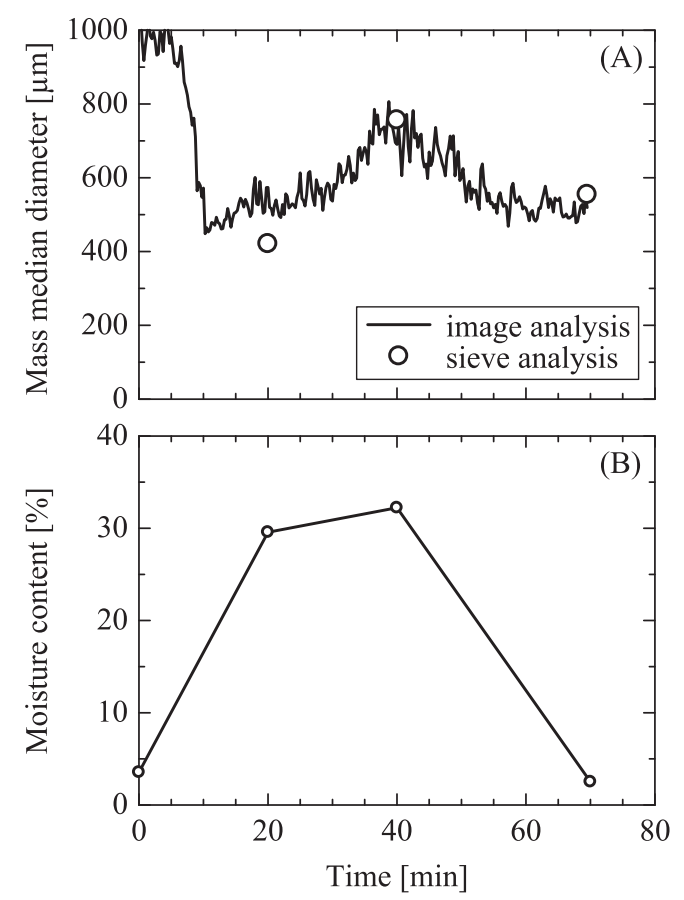

Fig. 4 Change in (A) mass median diameter and (B) moisture content in preliminary study at lab-scale

度を Fig. 8 および Table 6 に示す。Table 5 に示した総加 水量および造粒工程中の含水率最大值によらず，加水速 度を変化させたいずれの条件においても, 粒子径をオン ラインモニタリングして加水終点を制御することにより， 同等の物性を有する顆粒が得られた。 
Table 5 Experimental results about total amount of feed water and maximum of moisture content in each granulation process

\begin{tabular}{|c|c|c|c|}
\hline & i) Standard & ii) Slow & iii) Fast \\
\hline Total amount of feed water $[\mathrm{kg}]$ & 97.4 & 107.5 & 94.0 \\
\hline $\begin{array}{l}\text { Maximum of moisture content in } \\
\text { granulation process [\%] }\end{array}$ & 30.2 & 30.3 & 31.0 \\
\hline
\end{tabular}

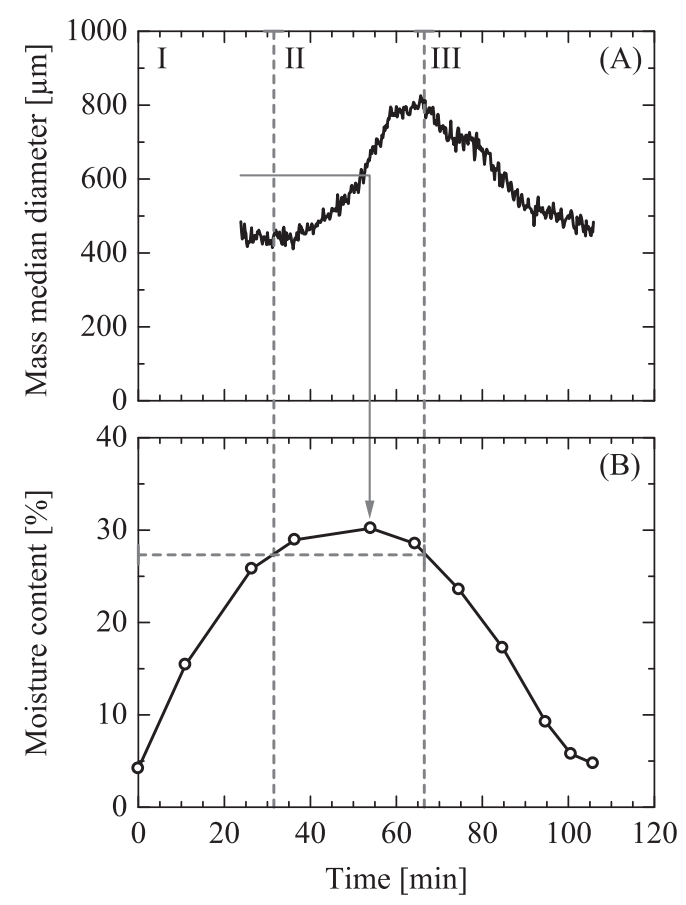

Fig. 5 Change in (A) mass median diameter and (B) moisture content in Standard condition at commercial scale (the threshold of moisture content is $27.3 \%$ )

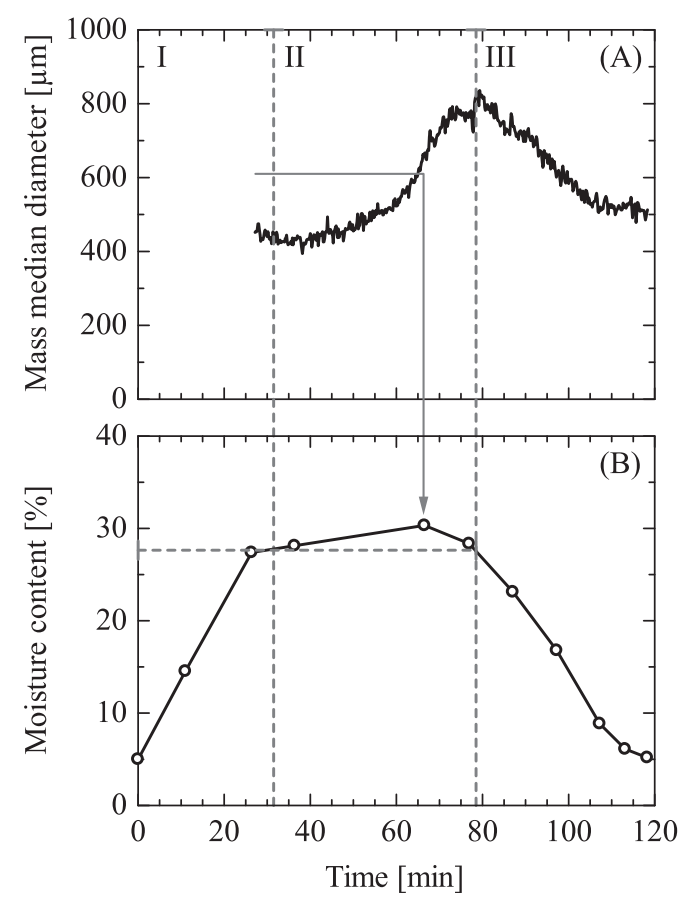

Fig. 6 Change in (A) mass median diameter and (B) moisture content in Slow condition at commercial scale (the threshold of moisture content is $27.7 \%$ )

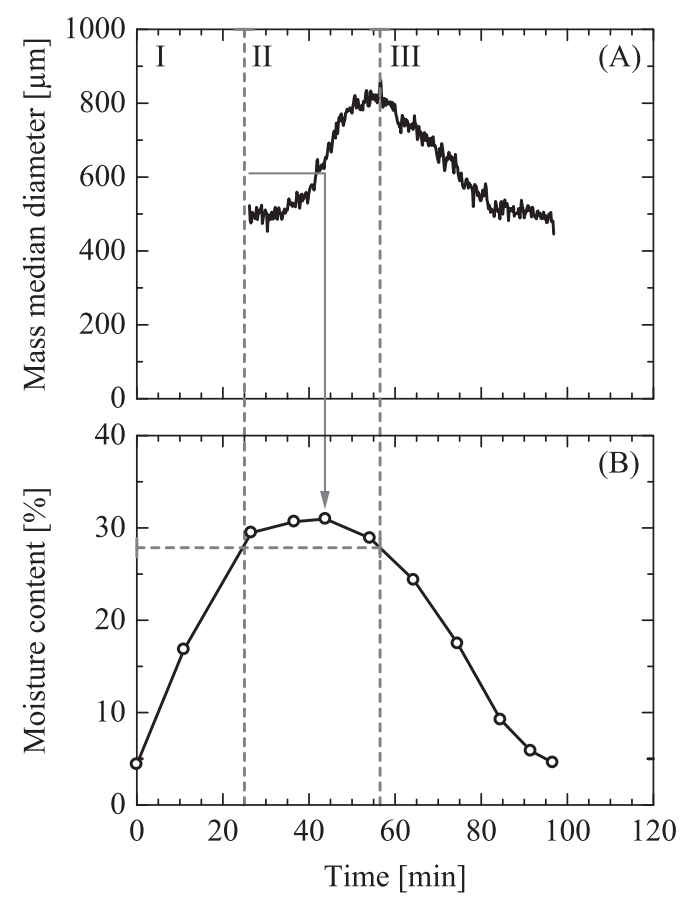

Fig. 7 Change in (A) mass median diameter and (B) moisture content in Fast condition at commercial scale (the threshold of moisture content is $27.9 \%$ )

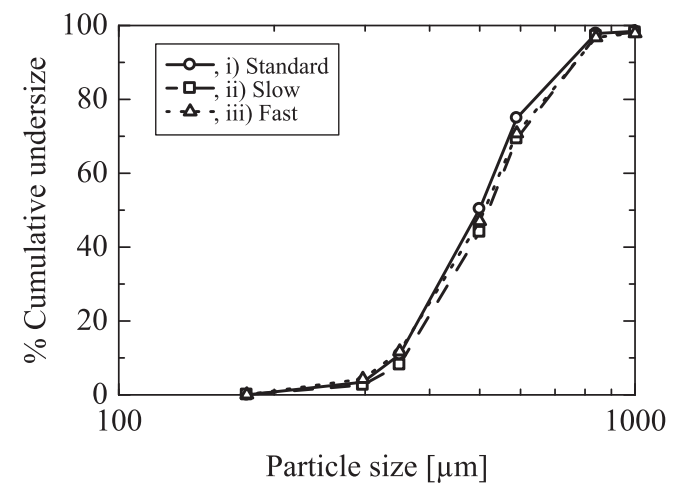

Fig. 8 Cumulative particle size distribution of granules

Table 6 Physical properties of granules

\begin{tabular}{lccc}
\hline & i) Standard & ii) Slow & iii) Fast \\
\hline Mass median diameter $[\mu \mathrm{m}]$ & 498 & 518 & 504 \\
Bulk density $\left[\mathrm{g} / \mathrm{cm}^{3}\right]$ & 0.68 & 0.68 & 0.68 \\
\hline
\end{tabular}

\section{4 流動層造粒機構の考察}

今回実験した各条件において, 総加水量はあまり重要 でなく, かつ, 加水終点と造粒成長の停止は必ずしも一 致しなかった。この時間差は, プロセスの遅延ではなく, 含水率が可塑限界值を下回る時間に一致しており, 含水 率と可塑限界值の大小関係が粒子径推移に大きく影響を 与えていることが明らかとなった。質量中位径の増加が 始まるときの含水率と, 質量中位径が最大值を示すとき の含水率が一致することは大変興味深い。前節の小スケー ル予備検討においても, 造粒工程中の含水率を十分な頻 度で評価することはできなかったものの, 同様の傾向が 確認された。 
これまで覺拌造粒工程での粒子成長機構に関して Wauters らは, 試料の飽和度に注目して, 核形成段階, 誘導段階, 粒子成長段階の三段階に分類し, 粒子成長過 程を解析している[22]。今回得られた結果は, Wauters ら が攪汼造粒工程での粒子成長に関して提案している粒子 成長機構を，流動層造粒工程においても適用できること を示唆する結果となった。Wauters らの試料が，本実験 と同様に，70\%以上無機塩を含む試料であった点も，類 似した結果をもたらした一因であると考えられる。流動 層造粒は攪拌造粒と異なり，乾燥まで一つのプロセスで 遂行することができる特徵をふまえ, Wauters らの粒子 成長機構を前節で分類した各段階は，（I）核形成および 誘導段階,（II）粒子成長段階，（III）解砕段階と名付け て以下のとおり説明することができる。

（I）核形成および誘導段階；はじめに，あらかじめ試 料粉体に混合しておいた結合剂が水に濡れて結合性を発 現することにより，顆粒の核となる粒子が形成される。 今回の試料については，この段階で質量中位径は約 $440 \mu \mathrm{m}$ まで到達すると考えられ，これは実験条件によっ て変化しなかった。

つづいて閾值を上回るまでの間，噴霧にともない粉体 は吸水を継続し，含水率が増加する。この期間，ほとん ど粒子径推移はみられない。これは，流動層造粒では攪 拌造粒などと比較して圧密がかかりにくいため, 粉体の 体積変化が無視できる範囲であると推察される。

（II）粒子成長段階；加水により含水率が増加し, 可塑 限界值を上回った場合, 系全体の粉体表面に自由水が存 在する。この自由水を結合剤として利用して，核形成お よび誘導段階において形成された粒子同士の凝集成長が 進行すると考えられる。全体の含水率が閾值を上回らな い時間帯であっても，局所的には，粉体表面に自由水が 存在する状況が考えられるが，粉体表面の水が十分量で はなく，粒子成長よりも繰り返し衝突を通じて，粉体全 体への水の再分配が起こっている可能性が考えられる。

粒子成長段階における, 各時点の質量中位径 $\mathrm{MMD}_{t}$ と 粒子成長段階の開始時点の質量中位径 $\mathrm{MMD}_{1}$ の比 $\mathrm{MMD}_{t} / \mathrm{MMD}_{1}$ を，含水率と閾值の差 $\left(W_{t}-W_{t h r}\right)$ の時間積 分に対して片対数プロットした図を Fig. 9 に示す。粒子 成長段階の初期質量中位径 $\mathrm{MMD}_{1}$ は $440 \mu \mathrm{m}$ とした。含 水率と閾值の差は, 粉体表面に存在する自由水を模式的 に表している。当該段階において，質量中位径は含水率 と閾値の差の時間積分の増大に伴い，指数関数的に増大 する傾向を認めた。さらに，加水速度によらず，同一曲 線上のプロットが得られたことから，この含水率と閾值 の差の時間積分は, 凝集現象の支配的要因の一つである と考えられる。すなわち, 粉体表面に存在する自由水に より，急激な凝集が進行していることが示唆される。な お，核形成および誘導段階の限られた時間においては粉 末添加した結合剂の全量が溶解せず，粒子成長段階にお いてもその溶解が進行しうるため，前段階にて未作用の 結合剤に起因する凝集成長の可能性も考慮されるべきで あるが，Fig. 9 の関係から，粒子成長段階における凝集

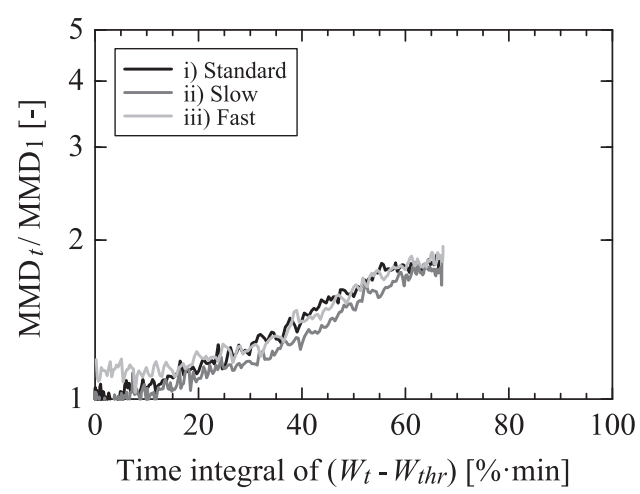

Fig. 9 Relation between $\mathrm{MMD}_{t} / \mathrm{MMD}_{1}$ and time integral of difference between moisture content at each time point and the threshold of moisture content

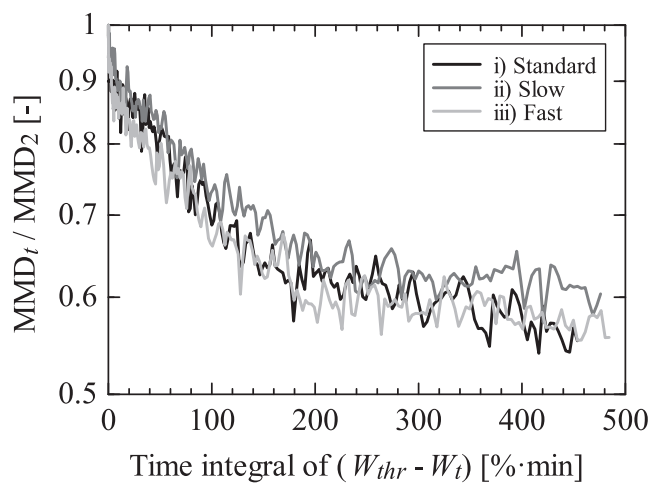

Fig. 10 Relation between $\mathrm{MMD}_{t} / \mathrm{MMD}_{2}$ and time integral of difference between the threshold of moisture content and moisture content at each time point

成長は粉体表面に存在する自由水に起因する可能性が高 いと考えた。また，今回実験した各条件において，造粒 工程中の最大質量中位径がほぼ同じ值であったのは, こ の含水率と閾值の差の時間積分がいずれの条件において もほぼ同じ值であったことが影響している可能性が高い と考えられる。

（III）解砕段階; 加水を停止しても今回のような粒子表 面に存在する水の結合力に起因する凝集現象は, すぐに は停止しない。乾燥が進行し，再び閾值を下回った時点 で，凝集は停止する。さらに，乾燥が進行すると造粒物 内部が多孔質になるため, 壊れやすい顆粒になる。しか し，流動層造粒においては，粉砕機のように大きな外力 を与えて積極的に粉砕しているわけではないので, 一次 粒子以下，すなわち，粒子成長段階の開始時点の質量中 位径 $\mathrm{MMD}_{1}$ 以下にはならないと考えられる。

解砕段階における, 各時点の質量中位径 $\mathrm{MMD}_{t}$ と解砕 段階の開始時点の質量中位径 $\mathrm{MMD}_{2}$ の比 $\mathrm{MMD}_{t} / \mathrm{MMD}_{2}$ を, 閾值と含水率の差 $\left(W_{t h r}-W_{t}\right)$ の時間積分に対して片 対数プロットした図を Fig. 10 に示す。解砕段階の初期質 量中位径 $\mathrm{MMD}_{2}$ は各条件における造粒工程中の最大質 量中位径とした。閾值と含水率の差は, 乾燥により粒子 内部に生じた空隙を模式的に表している。当該段階にお いて, 質量中位径は閾值と含水率の差の時間積分の増大 に伴い, 指数関数的に減少する傾向を認めた。さらに, 
加水速度によらず，同一曲線上のプロットが得られたこ とから, この閾值と含水率の差の時間積分は, 解砕現象 の支配的要因の一つであると考えられる。すなわち，粒 子内部に生じた空隙を起点として解砕が進行しているこ とが示唆される。ある程度乾燥が進むと, 質量中位径の 減少は鈍化し，ほぼ平衡状態に達した。今回実験した各 条件において，得られた造粒物の質量中位径がほぼ同じ 值であったのは，平衡に達した状態まで乾燥したことに よると考えられる。

なお，実験条件により閾值がわずかに変動する理由と しては，含水率の測定精度がそれほど高くないこと，含 水率は実測值の直線内挿により求めていること, 測定機 器間の同期ずれ，原料差などが挙げられる。

今回実験に用いた系は，結合剤などほかの添加剤を含 まない精製水を結合液としており，最終製品の組成に影 響を与えずに総加水量を任意に調整できるため，医薬品 製剂製造のレギュレーション上，柔軟性が高く好都合で ある。今回のように, PAT を活用して粒子径をオンライ ンモニタリングしながら, 加水量を制御することにより, 粒度を一定範囲に管理し品質を確保することに貢献でき ることが示された。さらに，可塑限界值と造粒機構の関 係性を解明でき，これまで以上に詳細な工程理解を実現 することができた。現時点ではまだ半経験則的ではある が，今後，上述の三分類に基づいて新規数理モデルの開 発や安定生産のための工程管理手法などを通じて, さら
なる工程理解の推進が期待される。

\section{4. 結}

流動層造粒工程中における含水率の時間変化が粒子径 に与える影響を調べるために, PAT として粒子径推移を オンラインモニタリングすることにより以下の示す知見 を得た。

（1）造粒が急激に成長する開始点は，含水率が可塑限界 值を上回った時点と一致することが判明した。

（2）造粒成長の終点は加水停止と一致せず，含水率が可 塑限界值を下回った時点で停止することが明らかと なった。

（3）結合液として水を用いて流動層造粒する場合，粉体 表面に存在する自由水により凝集が急激に進行し, 乾燥により生じた粉体内部の空隙を起点として解砕 が進行することが示唆された。

（4）オンラインモニタリングした粒子径に基づいて，加 水終点を制御することで，造粒物の粒子径を一定範 囲に管理可能であることが示唆される。

[謝辞］ミキサートルクレオメータ測定にご協力いただき ました（有）ファーマポリテック・植村俊信氏に深謝い たします。生産スケールでの実験デー夕を提供いただき ました塩野義製薬株式会社・田中良介氏, 高橋摩帆氏, 鈴木拓麻氏に深謝いたします。

\section{Nomenclature}

MMD : mass median diameter

MMDS: mass median diameter smoothed

$W \quad$ : moisture content

$\alpha \quad$ : weight parameter in Eq. (1)

\begin{tabular}{rll}
{$[\mu \mathrm{m}]$} & \multicolumn{2}{l}{ Subscript } \\
{$[\mu \mathrm{m}]$} & $t$ & $:$ time point of measurement by image processing \\
{$[\%]$} & & system \\
{$[-]$} & $t h r$ & $:$ threshold \\
& 1 & $:$ initial time point in coalescence growth stage \\
2 & $:$ initial time point in breakage stage
\end{tabular}

\section{References}

[1] ICH Expert Working Group, ICH Harmonized Tripartite Guideline, Pharmaceutical Development Q8, Revision 2, 2009.

[2] U.S. Department of Health and Human Services, Food and Drug Administration, Guidance for Industry, PAT - A Framework for Innovative Pharmaceutical Development, Manufacturing, and Quality Assurance, 2004.

[3] T. Mizuta, Seizo Risk to PAT Guidance oyobi PAT no Syuho, PDA J. GMP Val. Japan 7 (2005) 25-37.

[4] M. Fujiwara, W. Momose, K. Kuroda, T. Inatani, K. Yamashita, K. Sako, Proportional control of moisture content of granules by adjusting inlet air temperature in fluidized bed granulation using near-infrared spectroscopy, Adv. Powder Technol. 25 (2014) 704-709.

[5] H. Nakagawa, Y. Kikkawa, K. Matsuura, S. Tanabe, T. Watanabe, Implementation of enhanced $\mathrm{QbD}$ to drug product development, J. Japan Soc. Pharm. Mach. Eng. 24 (2015) 469-475.

[6] O. Atsuo, K. Terashita, K. Miyanami, Iyakuhin Seizo niokeru Kakuhan Zoryu, J. Soc. Powder Technol., Japan 24
(1987) 535-541.

[7] H. Leuenberger, Granulation, New techniques, Pharm. Acta Helv. 57 (1982) 72-82.

[8] P. Holm, T. Schaefer, H. G. Kristensen, Granulation in highspeed mixers Part V. Power consumption and temperature changes during granulation, Powder Technol. 43 (1985) 213223.

[9] P. Holm, T. Schaefer, H. G. Kristensen, Granulation in highspeed mixers Part VI. Effects of process conditions on power consumption and granule growth, Powder Technol. 43 (1985) 225-233.

[10] S. Schildcrout, Rheology of pharmaceutical granulations, J. Pharm. Pharmacol. 36 (1984) 502-505.

[11] S. Watano, T. Morikawa, K. Miyanami, Kinetics of granule growth in fluidized bed granulation with moisture control, Chem. Pharm. Bull. 43 (1995) 1764-1771.

[12] S. Watano, Direct control of wet granulation processes by image processing system, Powder Technol. 117 (2001) 163 172.

[13] A. Burggraeve, T. Van Den Kerhof, M. Hellings, J. P. 
Remon, C. Vervaet, T. De Beer, Evaluation of in-line spatial filter velocimetry as PAT monitoring tool for particle growth during fluid bed granulation, Eur. J. Pharm. Biopharm. 76 (2010) 138-146.

[14] C. Biggs, R. Boerefijin, M. Buscan, A. Salman, M. Holunslow, Fluidised bed granulation: modelling the growth and breakage kinetics using population balances., Proc. World Cong. Particle Technol., Sydney (2002) pp. 629-636.

[15] H. Tan, A. Salman, M. Holunslow, Kinetics of fluidised bed melt granulation V: Simultaneous modelling of aggregation and breakage, Chem. Eng. Sci. 60 (2005) 3847-3866.

[16] T. Tanino, Control of critical quality and performance attributes of powder in manufacturing processes of oral dosage forms and PAT application, J. Soc. Powder Technol., Japan 42 (2005) 638-647.

[17] D. Geldart, Types of gas fluidization, Powder Technol. 7 (1973) 285-292.
[18] T. Uemura, S. Uramatsu, M. Morizane, H. Ichikawa, Y. Fukumori, Usefulness of mixer torque rheometer for pharmaceutical design, Pharm Tech Japan 28 (2012) 605611.

[19] R. C. Rowe, G. R. Sadeghnejad, The rheology of microcrystalline cellulose powder/water mixes - measurement using a mixer torque rheometer, Int. J. Pharm. 38 (1987) 227-229.

[20] Nihon Funtai Kogyo Gijutsu Kyokai, Zoryu Handbook, Ohm (1991) p. 88.

[21] S. Watano, K. Miyanami, Image processing for on-line monitoring of granule size distribution and shape in fluidized bed granulation, Powder Technol. 83 (1995) 55-60.

[22] P. A. Wauters, B. Scarlett, L. X. Liu, J. D. Litster, G. M. Meesters, A population balance model for high shear granulation, Chem. Eng. Commun. 190 (2003) 1309-1334. 